\title{
Clear cell change in colonic adenomas: case report and review of the literature
}

\author{
Alexander Chan, Margaret Cho, Antonio Galvao Neto \\ Department of Pathology and Laboratory Medicine, NYU Langone Medical Center, New York, USA \\ Correspondence: Antonio Galvao Neto. Address: Department of Pathology and Laboratory Medicine, NYU Langone \\ Medical Center, New York, USA. E-mail: Antonio.GalvaoNeto@nyumc.org
}

Received: July 17, 2014

DOI : $10.5430 / c r c p . v 2 n 2 p 1$

Accepted: October 07, 2014

Online Published: December 04, 2014

\section{Abstract}

Clear cell change is a very rare finding in colonic adenomas and adenocarcinomas. The few described cases were predominantly in elderly male patients with a predilection for the left colon and rectum. Here we present the second case of clear cell morphology in a colonic adenoma with high-grade dysplasia, occurring in the ascending colon of an elderly female patient. Immunohistochemical and special stains analyses were performed showing findings similar to prior reports of this unusual morphologic entity and excluding the possibility of other synchronous tumors or metastases to the colon with clear cell morphology. A review of primary colonic tumors with clear cell features was also performed and is discussed here.

\section{Key words}

Clear cell, Adenocarcinoma, Tubular adenoma, Colonic adenoma, High grade dysplasia

\section{I ntroduction}

Clear cell change is a rare finding in colonic adenomas and adenocarcinomas. First described in $1964^{[1]}$, clear cell features are reported in both adenomas and adenocarcinomas and generally make up a portion of the lesion rather than the entire lesion ${ }^{[2]}$. These changes are typically seen in elderly male patients, with a predominance in the left colon ${ }^{[2,3]}$. Though these findings are rare, some small studies suggest that while clear cell changes are an unusual morphologic variant, they are associated with similar molecular and immunohistochemical findings to conventional colonic tumors, suggesting a common pathogenetic pathway ${ }^{[4]}$.

We present a rare case of clear cell change in colonic tubular adenoma with high grade dysplasia. This case occurred in an unusual demographic (female patient) and unusual location (right colon). An up to date review of the English-language literature regarding clear cell changes in primary colonic tumors is also performed and discussed herein.

\section{Case presentation}

A 75-year-old female presented to our institution in January, 2013 for treatment of a colonic polyp with high-grade dysplasia. The patient originally presented to an outside hospital for a screening colonoscopy, which disclosed a $1.5 \mathrm{~cm}$ polyp in the ascending colon which was not amenable to endoscopic removal. Pathologic evaluation of the polyp 
biopsy showed a tubular adenoma with high-grade dysplasia. The patient was scheduled at our institution for a right hemicolectomy for management of the high-grade dysplasia. An uncomplicated right hemicolectomy and bilateral salpingo-oophorectomy (for ovarian cysts) was performed.

Gross examination of the resected segment of colon and terminal ileum showed a $1.5 \mathrm{~cm} \times 1 \mathrm{~cm}$ irregular, flat polyp on the mucosa of the ascending colon, consistent with an adenoma without gross evidence of invasion. All surgical margins were free of tumor. The lesion and surrounding colonic tissue were entirely submitted for microscopic evaluation. The two adnexae received were grossly remarkable only for benign appearing, thin-walled ovarian cysts filled with clear fluid.

Microscopic examination of the lesion showed a tubular adenoma with high-grade dysplasia/carcinoma in situ. The majority of the polyp showed conventional adenoma with only small foci of high-grade dysplasia in one section. A distinct area of clear cell morphology was identified within the adenoma but sharply demarcated from the more conventional dysplastic glands. The area of clear cell change showed a tubular and occasionally cribriform growth pattern with clear cytoplasm, small haphazardly oriented nuclei and occasional conspicuous nucleoli (see Figure 1). The two ovaries showed benign serous cysts, a minute incidental thecoma and no evidence of adenocarcinoma. Both fallopian tubes were unremarkable.
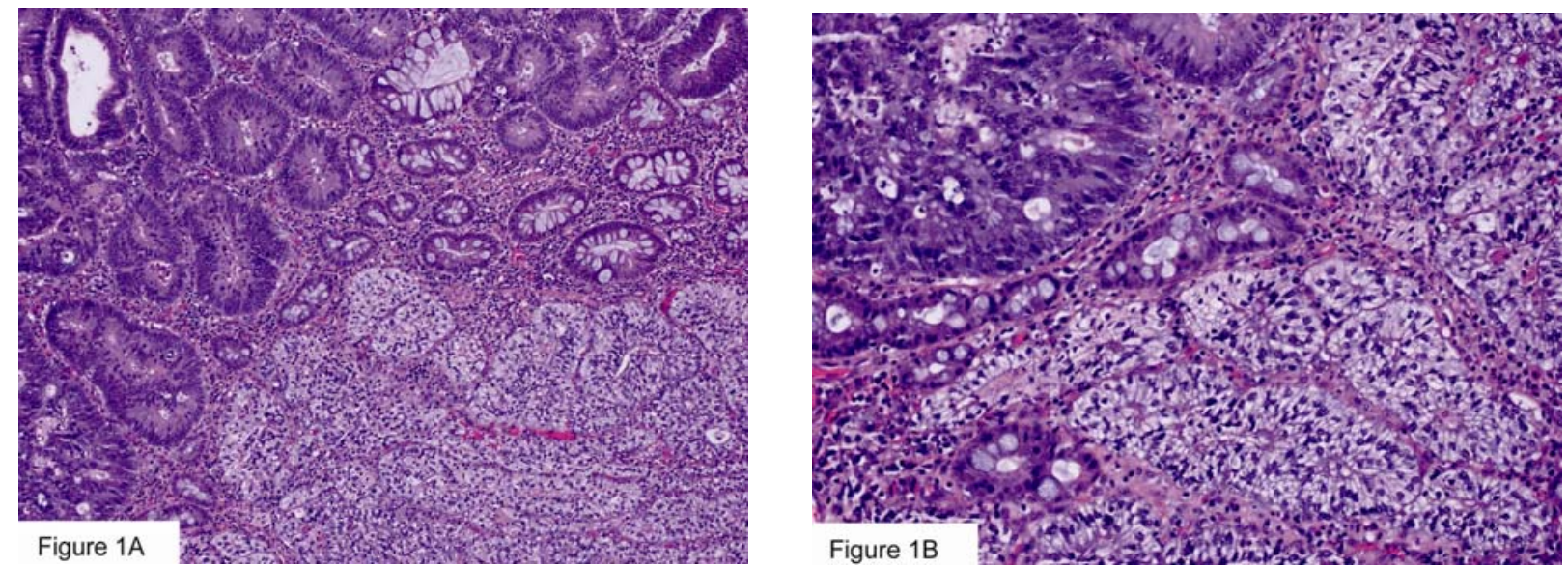

Figure 1. H\&E photomicrograph of adenoma with clear cell component. (A) 40× magnification shows clear cell component (bottom right) with conventional adenoma component (top left). (B) $100 \times$ magnification of clear cell component (bottom right) adjacent to conventional adenomatous component (top left) with high-grade dysplasia and cribriform architecture. (C) 400× magnification of clear cell component (bottom right) adjacent to conventional adenomatous component (top left).

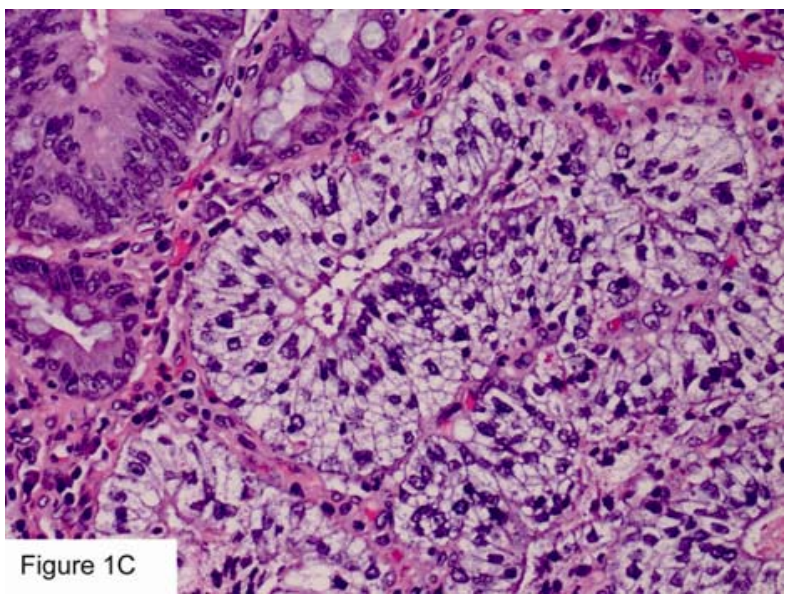

Immunohistochemical stains were performed on sections of the polyp and showed positive reactivity for cytokeratins AE1/AE3, CDX2 and focal CK20 positivity with concurrent negative staining for CK7 consistent with a primary colonic lesion (see Figure 2A-2C). This staining pattern was seen in both the conventional adenoma areas as well as the areas with clear cell changes. Ki-67 proliferative index was increased in both the clear cell areas as well as the conventional adenomatous areas, staining approximately $60 \%$ of the cells (see Figure 2D). The percentage of Ki-67 positive cells was 
similar between the clear cell and conventional adenomatous areas. A PAS stain performed was also negative for PAS positive cytoplasmic granules (see Figure 3A), and an Alcian Blue stain was negative for mucin in the clear cell areas (see Figure 3B). Staining for $\beta$-catenin showed diffuse nuclear positivity in the clear cell areas (see Figure 3C), and staining for p53 showed focal nuclear staining (see Figure 3D). Additional stains showed focal weakly positive reactivity for CD56, though staining for more specific neuroendocrine markers such as synaptophysin and chromogranin was negative. Additional molecular genetics studies were not performed.

Figure 2. Photomicrograph of immunohistochemical stains confirming colonic origin of lesion: (A) CK20 immunohistochemical stain shows focal positivity, (B) CDX2 immunohistochemical stain shows strong diffuse positivity, (C) CK7 immunohistochemical stain is negative, and (D) Ki-67 proliferative index shows an increased percentage of proliferating cells (approximately $60 \%$ ), similar in both the clear cell and conventional adenomatous areas.

Figure 3. Stains for (A) PAS show negative staining for PAS positive granules, (B) alcian blue (AB) shows negative staining in adenoma and clear cell areas with positive staining in normal glands, (C) $\beta$-catenin shows diffuse nuclear positivity, and (D) p53 shows focal nuclear positivity.
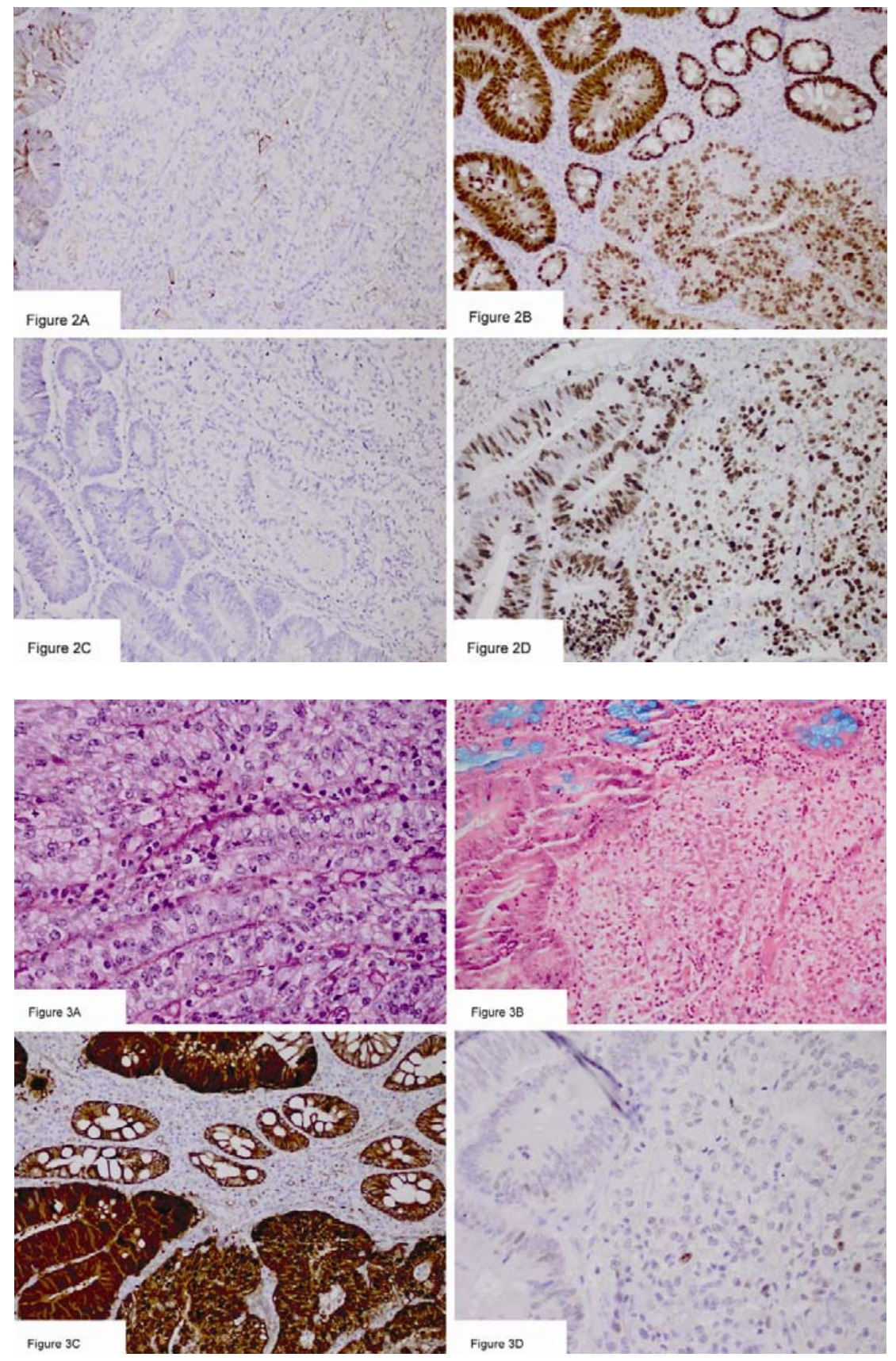

The microscopic impression confirmed the gross evaluation in which no invasive carcinoma was seen and all surgical margins were free of tumor. Seventeen lymph nodes were negative for tumor. The patient's postoperative course was unremarkable, and she was discharged soon after surgery. 


\section{Discussion}

Tubular adenomas are precursors to colonic adenocarcinomas and are commonly seen in the colon. Within tubular adenomas and adenocarcinomas a variety of unconventional differentiations or morphologies have been reported, including squamous, neuroendocrine and sarcomatoid differentiations ${ }^{[5]}$. However, clear cell morphology is very rarely reported. An up to date review of the English language literature identified 13 reported cases of clear cell change occurring in colonic adenoma and adenocarcinoma including the case reported here (see the table) ${ }^{[1-4,6-11]}$.

Table . Summary of cases of clear cell change in colonic adenoma and adenocarcinoma

\begin{tabular}{|c|c|c|c|c|c|c|c|c|c|c|c|c|}
\hline Case & Reference & Age & Sex & Site & Size (mm) & Diagnosis & AB & PAS & P53 & B-Cat & KRAS & Treatment \\
\hline 1 & Eloy, 2009 & 63 & M & Rectum & 2 & HP & - & - & - & - & NP & Polypectomy \\
\hline 2 & Eloy, 2009 & 68 & $\mathrm{~F}$ & Sigmoid & 5 & TA & - & - & + & - & NP & Polypectomy \\
\hline 3 & Eloy, 2009 & 84 & M & Sigmoid & 18 & TA & - & - & + & + & NP & Polypectomy \\
\hline 4 & $\begin{array}{l}\text { Domoto, } \\
1999\end{array}$ & 45 & M & Transverse & 60 & TA & - & - & - & NP & NP & Polypectomy \\
\hline 5 & $\begin{array}{l}\text { Domoto, } \\
1999\end{array}$ & 44 & M & Sigmoid & 100 & TA & - & - & + & NP & NP & Polypectomy \\
\hline 6 & $\begin{array}{l}\text { Suzuki, } \\
1998\end{array}$ & 62 & M & Descending & 14 & TA & - & - & - & NP & - & Polypectomy \\
\hline 7 & Eloy, 2009 & 48 & $\mathrm{~F}$ & Transverse & 25 & HGD & - & - & + & - & NP & Polypectomy \\
\hline 8 & Present Case & 75 & $\mathrm{~F}$ & Ascending & 15 & HGD & - & - & + & + & NP & Hemicolectomy \\
\hline 9 & $\begin{array}{l}\text { Barisella, } \\
2008\end{array}$ & 54 & M & $\begin{array}{l}\text { Hepatic } \\
\text { Flexure }\end{array}$ & 9 & $\mathrm{CCA}$ & NP & NP & + & + & + & $\begin{array}{l}\text { Total } \\
\text { Colectomy }\end{array}$ \\
\hline 10 & $\begin{array}{l}\text { Braumann, } \\
2004\end{array}$ & 89 & M & $\begin{array}{l}\text { Splenic } \\
\text { Flexure }\end{array}$ & 22 & $\mathrm{CCA}$ & - & - & NP & NP & NP & $\begin{array}{l}\text { Segmental } \\
\text { Resection }\end{array}$ \\
\hline 11 & Ko, 2007 & 62 & M & Sigmoid & 15 & $\mathrm{CCA}$ & NP & NP & NP & NP & NP & $\begin{array}{l}\text { Segmental } \\
\text { Resection }\end{array}$ \\
\hline 12 & Rubio, 1995 & 68 & M & $\begin{array}{l}\text { Splenic } \\
\text { Flexure }\end{array}$ & 60 & CCA & - & - & NP & NP & NP & Hemicolectomy \\
\hline 13 & Soga, 2008 & 71 & $\mathrm{~F}$ & Sigmoid & 8 & $\mathrm{CCA}$ & - & - & + & NP & NP & Polypectomy \\
\hline
\end{tabular}

Note. Reported cases of colonic primary tumors with clear cell change. B-Cat: $\beta$-Catenin; AB: alcian blue; PAS: periodic acid schiff; HP: Hyperplastic polyp; TA: Tubular adenoma; HGD: Adenoma with high-grade dysplasia; CCA: clear cell adenocarcinoma; NP: Not performed

Of those cases 9 of $13(69.2 \%)$ occurred in male patients. Eleven of $13(84.6 \%)$ occurred in the left colon. The average size reported was $27 \mathrm{~mm}$. Of the cases in which testing was performed, increased p53 expression was positive in 6 of 10 (60\%) and nuclear $\beta$-catenin staining was positive in 3 of $6(50 \%)$ cases. Six of $13(46.2 \%)$ were diagnosed as tubular adenomas. Including the current case, 2 of 13 (15.4\%) were adenomas with high-grade dysplasia. Five of 13 (38.5\%) were diagnosed as invasive adenocarcinomas. Eight of $13(61.5 \%)$ were treated endoscopically and the remainder were treated with surgical excision ${ }^{[1-4,6-11]}$. One retrospective study of 3486 colonic adenomas found changes in only 3 specimens $(0.086 \%)^{[2]}$. In the colon, the findings are associated with elderly patients and a slight predominance for the male gender. Lesions with clear cell change are typically seen in the left colon and rectum ${ }^{[2,3]}$. Our case is unusual because it occurred in a female patient in the ascending colon, and in a lesion with high-grade dysplasia.

The exact causes of clear cell change are still unknown. Glycogen is often implicated in other lesions with clear cell change but clear cell change in the colon is generally negative for glycogen granules when stained for PAS ${ }^{[1-3,6-10]}$. Clear cell lesions are also typically negative for alcian blue staining pointing to an absence of mucin in the clear cells ${ }^{[1-3,6-10]}$. Our case was negative for PAS staining granules and negative for mucin on Alcian Blue staining, consistent with previous reports.

The presence of clear cell change can be a diagnostic dilemma. They can often be seen associated with a variety of lesions including carcinomas and some sarcomas. Clear cell adenocarcinoma more commonly occurs in the kidneys (clear cell renal carcinoma), ovaries, uterus and cervix ${ }^{[3]}$. There are also reports of clear cell adenocarcinoma arising in 
endometriosis within the colon ${ }^{[12]}$. The kidneys and female genital tract organs all share a Mullerian origin which may partly explain this commonality ${ }^{[3]}$. As the differential diagnosis for clear cell adenocarcinoma in the colon is largely a matter of a primary versus metastatic or synchronous lesion, it is important for the pathologist to be aware of the existence of colonic primary tumors with clear cell morphology. It is critical for the pathologist not to over-diagnose metastatic lesions or synchronous tumors. Immunohistochemical stains such as panel including CK7/CK20 and CDX2 are useful to prove a gastrointestinal origin and eliminate the possibility of metastasis from other sites ${ }^{[13]}$. Review of patient's history, imaging studies and other investigations are also valuable in these situations.

The biological significance of clear cell change in colonic adenomas remains unknown. While its morphology is distinct, clear cell change in colonic adenocarcinomas probably arises from similar molecular mechanisms to conventional adenocarcinomas. In fact, in some studies the clear cell areas of these lesions showed positive reactivity to immunohistochemical stains for p53 and nuclear $\beta$-catenin ${ }^{[1,2,4,6-8,12]}$. Our case showed focal positive staining for p53 and diffuse nuclear positivity for $\beta$-catenin. Positive p53 staining suggests nuclear accumulation of a mutated p53 gene product, which affects multiple cell cycle genes, and positive nuclear reactivity with $\beta$-catenin is consistent with abnormal activation of the Wnt pathway associated with colonic tumorigenesis ${ }^{[14]}$. One study reported multiple foci of clear cell change associated with high-grade dysplasia and invasive adenocarcinoma with p53 overexpression present in both areas of clear cell change and in invasive carcinoma ${ }^{[15]}$. This study suggests that malignant progression can arise from clear cell foci, and the authors recommend that clear cell foci in colonic adenomas be considered as a high grade dysplasia equivalent with appropriate patient follow-up ${ }^{[15]}$. Some molecular studies have also shown cases to be positive for genetic changes associated with the development of colonic tumorigenesis such as activating KRAS mutations, which are found in approximately $40 \%$ of conventional colorectal adenocarcinomas and play an important role in treatment decisions ${ }^{[4,14]}$. These molecular findings suggest that clear cell changes in colonic adenomas and adenocarcinomas are a rare and distinct morphologic variant that follows similar pathways to conventional lesions ${ }^{[4]}$.

In summary, clear cell change in colonic adenomas is a rare finding and can be a diagnostic challenge. This case of clear cell change in a colonic adenoma with high grade dysplasia is unusual because of its location and clinical demographics. When confronted with a colonic lesion with clear cell change, awareness of the association can help pathologist to recognize primary colonic clear cell changes so as not to over-diagnose metastases or synchronous tumors, thus facilitating timely and proper therapy. It appears that clear cell morphology in colonic adenomas and adenocarcinomas is an unusual morphologic variant with similar pathogenesis to conventional colonic tumorigenesis, but may be considered as a high grade dysplasia equivalent, although its rarity makes its study difficult.

\section{References}

[1] Hellstrom HR, Fisher ER. Physaliferous variant of carcinoma of colon. Cancer. 1964; 17: 259-263. PMid: 14123687.

[2] Domoto H, Terahata S, Senoh A, Sato K, Aida S, Tamai S. Clear cell change in colorectal adenomas: its incidence and histological characteristics. Histopathology. 1999; 34: 250-256. PMid: 10217566. http://dx.doi.org/10.1046/j.1365-2559.1999.00598.x

[3] Braumann C, Schwabe M, Ordemann J, Jacobi CA. The clear cell adenocarcinoma of the colon: case report and review of the literature. Int J Colorectal Dis. 2004; 19: 264-267. PMid: 14557891. http://dx.doi.org/10.1007/s00384-003-0545-5.

[4] Barisella M, Lampis A, Perrone F, Carbone A. Clear cell adenocarcinoma of the colon is a unique morphological variant of intestinal carcinoma: Case report with molecular analysis. World Journal of Gastroenterology. 2008; 14(42): 6575-6577. PMid: 19030216. http://dx.doi.org/10.3748/wjg.14.6575

[5] Ouban A, Nawab RA, Coppola D. Diagnostic and pathogenetic implications of colorectal carcinomas with multidirectional differentiation: A report of 4 cases. Clin Colorectal Cancer. 2002; 1(4): 243-248. PMid: 12450423.

http://dx.doi.org/10.3816/CCC.2002.n.006

[6] Jewell LD, Barr JR, McCaughey WTE, et al. Clear-cell epithelial neoplasms of the large intestine. Arch Pathol Lab Med. 1988; 112: 197-199. PMid: 3276291. 
[7] Suzuki H, Ohta S, Tokuchi S, Moriya J, Fujioka Y, Nagashima K. Adenoma with clear cell change of the large intestine. J Surg Oncol. 1998; 67: 182-185. PMid: 9530889. http://dx.doi.org/10.1002/(SICI)1096-9098(199803)67:3<182::AID-JSO7>3.0.CO;2-5

[8] Eloy C, Lopes JM, Faria G, Moreira H, Brandao A, Silva T, et al. Clear cell change in colonic polyps. Int J Surg Pathol. 2009; 17(6): 438-443. PMid: 18611940. http://dx.doi.org/10.1177/1066896908319211

[9] Rubio CA. Clear cell adenocarcinoma of the colon. J Clin Pathol. 1995; 48: 1142-1144. PMid: 8568005.

[10] Soga K, Konishi H, Tatsumi N, et al. Clear cell adenocarcinoma of the colon: A case report and review of the literature. World J Gastroenterology. 2008; 14(7): 1137-1140. PMid: 18286700. http://dx.doi.org/10.3748/wjg.14.1137

[11] Ko YT, Baik SH, Kim SH, et al. Clear cell adenocarcinoma of the sigmoid colon. Int J Colorectal Dis. 2007; 22: 1543-1544. PMid: 17186251. http://dx.doi.org/10.1007/s00384-006-0257-8

[12] McCluggage WG, Desai V, Toner PG. Clear cell adenocarcinoma of the colon arising in endometriosis: a rare variant of primary colonic adenocarcinoma. J Clinical Pathol. 2011; 54: 76-79. PMid: 11271795. http://dx.doi.org/10.1136/jcp.54.1.76

[13] Taliano RJ, LeGolvan M, Resnick MB. Immunohistochemistry of colorectal carcinoma: current practice and evolving applications. Hum Pathol. 2013; 44: 151-163. PMid: 22939578. http://dx.doi.org/10.1016/j.humpath.2012.04.017

[14] Fearon ER. Molecular genetics of colorectal cancer. Ann Rev Pathol. 2011; 6: 479-507. PMid:21090969. http://dx.doi.org/10.1146/annurev-pathol-011110-130235

[15] Usztaszeri M and Bouzourene H. Invasive carcinoma arising from a colonic adenoma with clear cell change. Human Pathology. 2008; 39: 1402-1405. PMid: 18602669. http://dx.doi.org/10.1016/j.humpath.2008.01.008 